\title{
Heavy metal pollution potential in soil influenced by sawmill operations at Ado-ekiti, Nigeria
}

\author{
E. I. Adeyeye ${ }^{1 *}$, O. S. Shittu ${ }^{2}$, O. J. Ayodele ${ }^{2}$ and A. O. A. Ilori ${ }^{2}$ \\ ${ }^{1}$ Department of Chemistry (Analytical Unit), Ekiti State University, PMB 5363, Ado-Ekiti, Nigeria \\ ${ }^{2}$ Department of Soil Resources and Environmental Management, Ekiti State University, PMB 5363, Ado-Ekiti, Nigeria
}

\begin{abstract}
Pollution potentials of heavy metals in soils around a Sawmill at Ado-Ekiti, Nigeria were evaluated. The geo-accumulation $\left(\mathrm{I}_{\text {geo }}\right)$ values were positive, less than 1.0 and within Class $1 \mathrm{I}_{\text {geo }}$ grade indicating none to moderate pollution of the soils by the heavy metals. Chi-square analysis showed that the $\mathrm{I}_{g e o}$ values were not significantly different at the various sampling distances indicating that the heavy metals were not spatially influenced in the soils. $\mathrm{Co}, \mathrm{Zn}, \mathrm{Ni}, \mathrm{Pb}, \mathrm{Cd}$ and $\mathrm{Cr}$ had positive Relative Pollution Potential (RPP) values at all sampling points with a few exceptions whereas, As and $\mathrm{Cu}$ had negative RPP except As $(90 \mathrm{~m},+0.93 ; 125 \mathrm{~m},+0.15)$. The positive RPP values indicate the metals were likely introduced at the impact point while negative RPP values (As and $\mathrm{Cu}$ ) would be from lithological sources but the Chi-square values were not significantly different. The indices did not point to serious pollution concerns.
\end{abstract}

Keywords: Sawmill soils; Heavy metals; Geoaccumulation index; Relative pollution potentials

\section{Introduction}

Increasing demand for timber products as building materials, furniture, industrial and domestic uses, artistic designs and decorative purposes due to rapid urbanization and civilization has projected the development of timber processing industries such as sawmills particularly in Ekiti State and the rain forest zone of Nigeria at large. Wood wastes from sawmilling activities are generated from different tree species and made up by bark, sawdust, slab, strips and substandard timbers and logs left to decay (Panshin et al., 1950) and the relative increase in heavy metals contents in timber dump sites and soils in sawmills has been attributed to sawmill wastes (Okonkwo et al., 2013; Osakwe, 2013) rather than being derived from the mineralogy and the weathering (Karbassi et al., 2008).

Pollution of the natural environment by heavy metals is a worldwide problem as these metals are permanent and non-degradable in the soil and most of them have toxic effects on living organisms at certain concentrations (Chakra-borty et al., 2009), the risk of which arises primarily from the mobility or transportation to water resources and bioavailability of heavy metals in the environment (Adriano et al., 2002). Pollution indices are the tools used for evaluating the pollution potentials of heavy metals in soil, water and the environment (Egharevba and Odjada, 2002; Kargar et al., 2012; Wang et al., 2013; Ololade, 2014; Inengite et al., 2015; Achadu et al., 2016). The increasing sawmilling activities thus necessitated the need for this work, conducted to evaluate the pollution potentials of heavy metals in soils in a Sawmill at Ado-Ekiti, Ekiti State, Nigeria using geoaccumulation index and relative pollution potential.

\section{Materials and methods}

\section{Samples collection and chemical analyses}

Surface $(0-15 \mathrm{~cm})$ and subsurface $(15-30 \mathrm{~cm})$ soil samples were taken using auger, from a Sawmill of over 20 years of operation in Ado-Ekiti, Nigeria at varying distances of 0,30 , 60,90 and $125 \mathrm{~m}$ with $0 \mathrm{~m}$ being the point of impact or reference point and a background sample taken from an adjacent fallow land. The soil samples were air dried, crushed and screened through a $2 \mathrm{~mm}$ mesh size plastic sieve prior to chemical analysis. Total contents of $\mathrm{As}, \mathrm{Cd}, \mathrm{Cr}, \mathrm{Co}, \mathrm{Cu}, \mathrm{Pb}$, $\mathrm{Ni}$ and $\mathrm{Zn}$ were determined from one gram (1g) samples digested with $100 \mathrm{ml}$ concentrated $\mathrm{HNO}_{3}$ and $\mathrm{HClO}_{4}$ in ratio 2:1 on a Tecator Digestion system and were determined on atomic absorption spectrophotometer (AAS, Buck Scientific 205 Model) (Ayodele and Shittu, 2016). The heavy metals concentrations obtained were used to calculate the geo-accumulation indices and relative pollution potentials in order to evaluate the pollution potentials of heavy metals in the soils found in a sawmill.

\section{Geoaccumulation index $\left(I_{\text {geo }}\right)$}

Geoaccumulation index, $\mathrm{I}_{g e o}$ indicates the degree of pollution of soil with regards to the geochemical background concentrations of the polluting heavy metals. The $\mathrm{I}_{\text {geo }}$ values

\footnotetext{
*Corresponding author e-mail: adeyeyeilesanmi2012@gmail.com
} 
were calculated using the equation first proposed by Muller (1969), by multiplying the geochemical background concentrations of the metals each time by a constant, 1.5 in order to allow content fluctuations of a given substance in the environment as well as very small anthropogenic influences (Loska et al., 1997). Geo-accumulation index is

Table I. Distinguished classes of geo-accumulation index of heavy metals

\begin{tabular}{|c|c|c|}
\hline $\begin{array}{l}\text { Igeo } \\
\text { class }\end{array}$ & I geo value & Designation of quality \\
\hline 0 & $\mathrm{I}_{g e o} \leq 0$ & Unpolluted \\
\hline 1 & $0<\mathrm{I}_{\text {geo }}<1$ & Unpolluted to moderately polluted \\
\hline 2 & $1<\mathrm{I}_{g e o}<2$ & Moderately polluted \\
\hline 3 & $2<\mathrm{I}_{\text {geo }}<3$ & Moderately to strongly polluted \\
\hline 4 & $3<\mathrm{I}_{g e o}<4$ & Strongly polluted \\
\hline 5 & $4<\mathrm{I}_{\text {geo }}<5$ & Strongly polluted to extremely polluted \\
\hline 6 & $5<$ I geo & Extremely polluted \\
\hline
\end{tabular}

Source: Muller (1981)

mathematically expressed in equation (1) below and distinguished classes shown in Table I:

$\mathrm{I}_{\text {geo }}=\log _{2} C_{n} / 1.5 B_{n}$

where,

$\mathrm{C}_{\mathrm{n}}=$ concentration of the examined element in the examined environment, and

$\mathrm{B}_{\mathrm{n}}=$ geochemical background of a given element in reference environment.

\section{Relative pollution potential of the metals}

Relative pollution potential of a metal (pollutant) is a measure of the level of chemical interaction between the pollutant and the recipient. This was calculated using the method of Egharevba and Odjada (2002) as expressed in equation (2) and positive values indicate that the soils were contaminated at the point of impact and vice-versa.

$\mathrm{Y}=\frac{A-B}{A}$

Where:

$\mathrm{Y}=$ Relative pollution potential

$\mathrm{A}=$ Metal concentration at impacted point

$\mathrm{B}=$ Metal concentration at point away from the impacted point.

Obtained values were further subjected to simple descriptive statistics using means and coefficient of variation (CV \%) and Chi-square analyses. In order to distinguish the pollution potentials of the heavy metals, Aweto (1982) scale of variability was employed as follows:
Low variation $(\mathrm{CV}<20 \%)$

Moderate variation $(\mathrm{CV} \geq 20<50 \%)$

High variation $(\mathrm{CV}>50 \%)$

\section{Results and discussion}

Geoaccumulation index $\left(\mathrm{I}_{\text {geo }}\right)$ of the heavy metals

The geo-accumulation indices $\left(\mathrm{I}_{\text {geo }}\right)$ calculated for the assessed heavy metals in soils in a Sawmill in Ado-Ekiti, Nigeria were shown in Table II. Generally, the $I_{g e o}$ values obtained were all positive and below 1 which classified them within Class $1 \mathrm{I}_{\text {geo }}$ grade $\left(0<\mathrm{I}_{\text {geo }}<1\right)$, indicating unpolluted to moderately polluted soils by the heavy metals evaluated. The positive $\mathrm{I}_{\text {geo }}$ values are indications that the heavy metals in soils in the Sawmill were mainly from anthropogenic sources expectedly from the sawmilling activities rather than from the lithological sources that formed the soils. On the average, the $I_{g e o}$ values of the subsurface soils were higher than those of the surface soils at the Sawmill except at $30 \mathrm{~m}$ sampling distance/point. Similar results of Class $1 \mathrm{I}_{\text {geo }}$ were reported by Adaikpoh (2013) and Ololade (2014) in dumpsites and automobile workshops soils, respectively. Contrarily, Inengite et al. (2015) reported the year 2012 flooded soil of Niger Delta University, Bayelsa State, Nigeria to be of Class $0 \mathrm{I}_{\text {geo }}$ (unpolluted, $\mathrm{I}_{\text {geo }}<0$ ) with the similarly evaluated heavy metals except $\mathrm{Pb}$ which was Class $1 \mathrm{I}_{\text {geo }}\left(0<\mathrm{I}_{\text {geo }}<1\right)$ at the topsoil and Class $2 \mathrm{I}_{\text {geo }}\left(1<\mathrm{I}_{\text {geo }}<2\right)$ at the subsoil.

$\mathrm{Co}, \mathrm{As}, \mathrm{Cr}$ and $\mathrm{Cu}$ had higher $\mathrm{I}_{g e o}$ values at the subsurface depth compared to surface depth with the exception of $\mathrm{Cr}$ at $90 \mathrm{~m}\left(\mathrm{I}_{\text {geo }}=0.04\right)$ and $125 \mathrm{~m}\left(\mathrm{I}_{\text {geo }}=0.03\right)$ sampling distances. On the other hand, $\mathrm{Zn}, \mathrm{Ni}, \mathrm{Pb}$ and $\mathrm{Cd}$ had higher $\mathrm{I}_{\text {geo }}$ values at the surface depth except for $\mathrm{Ni}\left(\mathrm{I}_{\text {geo }}=0.15\right)$ and $\mathrm{Pb}\left(\mathrm{I}_{\text {geo }}=\right.$ $0.47)$ at $125 \mathrm{~m}$ sampling distances. Irrespective of the sampling distances and depths, the $\mathrm{I}_{g e o}$ values had high variations ranging from $50.8-116 \%$. The geo-accumulation $\left(\mathrm{I}_{\text {geo }}\right)$ values of the heavy metals in soils in the Sawmill across the sampling distances were shown in Table III. The $\mathrm{I}_{\text {geo }}$ values for the metals in the soil does not exhibit a regular pattern of variation on the basis of the sampling distances, ranging from little to high variations $(2.95 \% \mathrm{~Pb}-138 \% \mathrm{Ni})$. The $\mathrm{I}_{\text {geo }}$ values subjected to Chi-square $\left(\chi^{2}\right)$ analyses were not significantly different for all the metals at the various sampling distances indicating that the heavy metals were not spatially influenced. Spatially, $I_{g e o}$ mean values for the heavy metals also does not follow a particular trend on the basis of sampling distances but were in the order of $\mathrm{Cd}>\mathrm{Pb}>\mathrm{Cu}>$ $\mathrm{Zn}>\mathrm{As}>\mathrm{Co}>\mathrm{Ni}>\mathrm{Cr}$ considering the overall average, with $\mathrm{Cd}$ been the heavy metal with the most predominant pollution potential in the soils found in the Sawmill evaluated.

Relative pollution potentials of the heavy metals

The relative pollution potentials (RPP) of the heavy metals across the sampling depths were presented in Table IV. The 
Table II. Geo-accumulation index $\left(I_{g e o}\right)$ of metals across depths

\begin{tabular}{lrccccccccccc}
\hline $\begin{array}{l}\text { Dist }- \\
\text { ance } \\
(\mathrm{m})\end{array}$ & $\begin{array}{c}\text { Soil } \\
\text { depth }\end{array}$ & $\mathrm{Co}$ & $\mathrm{Zn}$ & $\mathrm{Ni}$ & $\mathrm{Pb}$ & $\mathrm{As}$ & $\mathrm{Cd}$ & $\mathrm{Cr}$ & $\mathrm{Cu}$ & $\mathrm{Mean}$ & $\mathrm{SD}$ & $\mathrm{CV} \%$ \\
\hline 0 & $0-15$ & 0.09 & 0.34 & 0.18 & 0.80 & 0.22 & 0.68 & 0.09 & 0.09 & 0.31 & 0.28 & 89.9 \\
& $15-30$ & 0.33 & 0.17 & 0.07 & 0.11 & 0.26 & 0.25 & 0.10 & 0.32 & 0.20 & 0.10 & 50.8 \\
30 & $0-15$ & 0.01 & 0.24 & 0.08 & 0.54 & 0.24 & 0.24 & 0.07 & 0.16 & 0.20 & 0.16 & 83.3 \\
& $15-30$ & 0.33 & 0.11 & 0.001 & 0.40 & 0.29 & 0.18 & 0.09 & 1.20 & 0.33 & 0.38 & 116 \\
60 & $0-15$ & 0.01 & 0.32 & 0.20 & 0.33 & 0.25 & 0.64 & 0.08 & 0.26 & 0.26 & 0.19 & 72.6 \\
& $15-30$ & 0.10 & 0.31 & 0.05 & 0.13 & 0.32 & 0.12 & 0.09 & 0.36 & 0.19 & 0.12 & 66.6 \\
90 & $0-15$ & 0.03 & 0.32 & 0.16 & 0.27 & 0.15 & 0.52 & 0.05 & 0.04 & 0.19 & 0.17 & 88.3 \\
& $15-30$ & 0.07 & 0.17 & 0.13 & 0.18 & 0.50 & 0.15 & 0.04 & 0.08 & 0.17 & 0.14 & 87.5 \\
125 & $0-15$ & 0.02 & 0.29 & 0.15 & 0.47 & 0.19 & 0.84 & 0.21 & 0.16 & 0.29 & 0.26 & 88.1 \\
& $15-30$ & 0.33 & 0.16 & 0.19 & 0.49 & 0.29 & 0.06 & 0.03 & 0.36 & 0.24 & 0.16 & 65.8 \\
\hline
\end{tabular}

Table III. Geo-accumulation index $\left(\mathrm{I}_{g e o}\right)$ of metals across sampling distances

\begin{tabular}{|c|c|c|c|c|c|c|c|c|c|}
\hline $\begin{array}{l}\text { Distan - } \\
\text { ce (m) }\end{array}$ & $\begin{array}{l}\text { Soil depth } \\
(0-30 \mathrm{~cm})\end{array}$ & Co & $\mathrm{Zn}$ & $\mathrm{Ni}$ & $\mathrm{Pb}$ & As & $\mathrm{Cd}$ & $\mathrm{Cr}$ & $\mathrm{Cu}$ \\
\hline \multirow[t]{4}{*}{0} & Mean & 0.21 & 0.26 & 0.13 & 0.46 & 0.24 & 0.47 & 0.10 & 0.21 \\
\hline & $\mathrm{SD}$ & 0.17 & 0.12 & 0.08 & 0.49 & 0.03 & 0.30 & 0.01 & 0.16 \\
\hline & $\mathrm{CV} \%$ & 80.8 & 47.1 & 62.2 & 107 & 11.8 & 65.4 & 7.44 & 79.3 \\
\hline & Range value & 0.24 & 0.17 & 0.11 & 0.69 & 0.04 & 0.43 & 0.01 & 0.23 \\
\hline \multirow[t]{4}{*}{30} & Mean & 0.17 & 0.18 & 0.04 & 0.47 & 0.27 & 0.21 & 0.08 & 0.68 \\
\hline & $\mathrm{SD}$ & 0.23 & 0.09 & 0.06 & 0.10 & 0.04 & 0.04 & 0.01 & 0.74 \\
\hline & $\mathrm{CV} \%$ & 133 & 52.2 & 138 & 21.1 & 13.3 & 20.2 & 17.7 & 108 \\
\hline & Range value & 0.32 & 0.13 & 0.079 & 0.14 & 0.05 & 0.06 & 0.02 & 1.04 \\
\hline \multirow[t]{4}{*}{60} & Mean & 0.06 & 0.32 & 0.13 & 0.23 & 0.29 & 0.38 & 0.09 & 0.31 \\
\hline & $\mathrm{SD}$ & 0.06 & 0.01 & 0.11 & 0.14 & 0.05 & 0.37 & 0.01 & 0.07 \\
\hline & CV \% & 116 & 2.24 & 84.9 & 61.5 & 17.4 & 96.8 & 8.22 & 22.8 \\
\hline & Range value & 0.09 & 0.01 & 0.15 & 0.20 & 0.07 & 0.52 & 0.01 & 0.10 \\
\hline \multirow[t]{4}{*}{90} & Mean & 0.05 & 0.25 & 0.15 & 0.23 & 0.24 & 0.34 & 0.05 & 0.06 \\
\hline & $\mathrm{SD}$ & 0.03 & 0.11 & 0.02 & 0.06 & 0.12 & 0.26 & 0.01 & 0.03 \\
\hline & $\mathrm{CV} \%$ & 56.6 & 43.3 & 14.6 & 28.3 & 51.2 & 78.1 & 15.7 & 47.1 \\
\hline & Range value & 0.04 & 0.15 & 0.03 & 0.09 & 0.35 & 0.37 & 0.01 & 0.04 \\
\hline \multirow[t]{4}{*}{125} & Mean & 0.18 & 0.23 & 0.17 & 0.48 & 0.24 & 0.45 & 0.12 & 0.26 \\
\hline & $\mathrm{SD}$ & 0.22 & 0.09 & 0.03 & 0.01 & 0.07 & 0.55 & 0.13 & 0.14 \\
\hline & $\mathrm{CV} \%$ & 125 & 40.9 & 16.6 & 2.95 & 29.5 & 123 & 106 & 54.4 \\
\hline & Range value & 0.05 & 0.13 & 0.04 & 0.29 & 0.10 & 0.78 & 0.18 & 0.20 \\
\hline \multicolumn{2}{|c|}{ Chi -square $\left(\chi^{2}\right)$ test } & 0.162 & 0.025 & 0.080 & 0.185 & 0.008 & 0.116 & 0.030 & 0.696 \\
\hline & Remark & NS & NS & NS & NS & NS & NS & NS & NS \\
\hline
\end{tabular}


Table IV. Relative pollution potentials of the metals across depths

\begin{tabular}{lrrrrrrrr}
\hline \multirow{2}{*}{ Metals } & Soil depth & \multicolumn{9}{c}{ Distance $(\mathrm{m})$} & \multicolumn{1}{c}{ Mean } & SD & CV \% \\
\cline { 3 - 5 } & \multicolumn{1}{c}{$(\mathrm{cm})$} & 30 & 60 & 90 & 125 & & & \\
\hline $\mathrm{Co}$ & $0-15$ & 0.83 & 0.87 & 0.67 & 0.80 & 0.79 & 0.89 & 10.9 \\
& $15-30$ & 0.00 & 0.70 & 0.80 & 0.00 & 0.38 & 0.43 & 116 \\
$\mathrm{Zn}$ & $0-15$ & 0.30 & 0.05 & 0.05 & 0.14 & 0.14 & 0.12 & 87.3 \\
& $15-30$ & 0.32 & -0.81 & 0.00 & 0.02 & 0.29 & 0.38 & 131 \\
$\mathrm{Ni}$ & $0-15$ & 0.54 & -0.08 & 0.09 & 0.19 & 0.23 & 0.22 & 95.9 \\
& $15-30$ & 0.98 & 0.35 & -0.75 & -1.62 & 0.93 & 0.53 & 57.5 \\
$\mathrm{~Pb}$ & $0-15$ & 0.33 & 0.58 & 0.67 & 0.42 & 0.50 & 0.15 & 30.7 \\
& $15-30$ & -0.38 & 0.56 & 0.38 & -0.69 & 0.50 & 0.15 & 30.1 \\
$\mathrm{As}$ & $0-15$ & -0.08 & -0.12 & 0.93 & 0.15 & 0.32 & 0.41 & 127 \\
& $15-30$ & -0.14 & -0.25 & -0.93 & -0.14 & 0.37 & 0.38 & 104 \\
$\mathrm{Cd}$ & $0-15$ & 0.65 & 0.12 & 0.18 & -0.24 & 0.30 & 0.24 & 80.7 \\
& $15-30$ & 0.28 & 0.53 & 0.41 & 0.75 & 0.49 & 0.20 & 40.6 \\
$\mathrm{Cr}$ & $0-15$ & 0.24 & 0.09 & 0.45 & -1.42 & 0.55 & 0.60 & 109 \\
& $15-30$ & 0.09 & 0.15 & 0.63 & 0.70 & 0.39 & 0.32 & 80.7 \\
$\mathrm{Cu}$ & $0-15$ & -0.80 & -1.80 & -0.60 & -0.80 & 1.0 & 0.54 & 54.2 \\
& $15-30$ & -2.75 & -0.75 & 0.75 & -2.75 & 1.13 & 1.10 & 97.4 \\
\hline
\end{tabular}

results showed that $\mathrm{Co}, \mathrm{Zn}, \mathrm{Ni}, \mathrm{Pb}, \mathrm{Cd}$ and $\mathrm{Cr}$ had positive RPP values in the soils with the exception of few sampling distances and depths for some of these heavy metals; $\mathrm{Pb}$ at 30 and $125 \mathrm{~m}$ subsurface depth, $\mathrm{Zn}$ at $60 \mathrm{~m}$ subsurface depth, $\mathrm{Ni}$ at $60 \mathrm{~m}$ surface depth and 90 and $125 \mathrm{~m}$ subsurface depths and $\mathrm{Cd}$ and $\mathrm{Cr}$, both at $125 \mathrm{~m}$ surface depth. Conversely, As and $\mathrm{Cu}$ had basically negative RPP in the studied soils found in the Sawmill except for As at 90 (0.93) and $125 \mathrm{~m}(0.15)$ sampling points at the surface depth.

It could be inferred from the values obtained according to Egharevba and Odjada (2002) that the assessed heavy metals with positive RPP values were introduced to the sawmill soils at the point of impact or contamination $(0 \mathrm{~m})$ whereas, negative RPP values (As and $\mathrm{Cu}$ ) were not infused to the soils at the point of impact which could rather be from lithological sources. Osakwe (2014) also reported positive RPP values for some heavy metals in selected automobile workshops soils within Abraka metropolis, Delta State, Nigeria. All the heavy metals had higher RPP mean values at the subsoil depth except $\mathrm{Co}$ and $\mathrm{Cr}$ but $\mathrm{Pb}$ was indifferent at both depths (0.55). They all exhibited moderate $(\mathrm{CV} \geq 20<50 \%)$ to high $(\mathrm{CV}>50 \%)$ variations at both depths across all the sampling points. However, Co showed a low variation $(\mathrm{CV}=10.92 \%)$ at the surface depth.
Table $\mathrm{V}$ presented the relative pollution potentials (RPP) of the heavy metals across the sampling distances in the Sawmill. The RPP values for Co and $\mathrm{Zn}$ ranged from $0.00-$ 0.87 and $-0.81-0.32$ respectively, with $60 \mathrm{~m}$ sampling point having the highest mean values of 0.79 and 0.43 accordingly. They had high variations $(\mathrm{CV}>50 \%)$ except at 60 and $90 \mathrm{~m}$ $(\mathrm{CV}=15.3 \%$ and $12.5 \%$, respectively) for Co and at $30 \mathrm{~m}$ $(\mathrm{CV}=4.56)$ for $\mathrm{Zn}$ compared to other sampling distances/points. $\mathrm{Ni}$ and $\mathrm{Cr}$ had moderate to high variations in the RPP values in the soils irrespective of the sampling distance with $125 \mathrm{~m}$ sampling distance having the highest mean values of 0.91 and 1.06 respectively.

$\mathrm{Cd}$ and $\mathrm{Cu}$ exhibited RPP values with high variations (CV > $50 \%$ ) at all the sampling distances except at $90 \mathrm{~m}$ point for $\mathrm{Cu}(\mathrm{CV}=15.7 \%)$ with low variation that could be due to the possible lithological source of $\mathrm{Cu}$ in the sawmill soils. $125 \mathrm{~m}$ sampling point also had the highest mean values for $\mathrm{Cd}$ (0.50) and $\mathrm{Cu}(1.78)$, also at $30 \mathrm{~m}$ sampling point. $\mathrm{Pb}$ and $\mathrm{As}$ had the highest RPP mean values of 0.57 and 0.93 at $60 \mathrm{~m}$ and $90 \mathrm{~m}$ sampling distances respectively, with low (CV < $20 \%)$ to moderate $(\mathrm{CV} \geq 20<50 \%)$ variations. Generally, all the heavy metals assessed had the RPP values ranged from $-2.75(\mathrm{Cu}$, at 60 and $125 \mathrm{~m}$ sampling points) to 0.93 (As, at 90 $\mathrm{m}$ sampling point) with a non-significant Chi-square $\left(\chi^{2}\right)$ values for all the heavy metals in soils found in a Sawmill at 
Table V. Relative pollution potentials of the metals across sampling distances

\begin{tabular}{|c|c|c|c|c|c|c|c|}
\hline \multirow[b]{2}{*}{ Metals } & \multirow{2}{*}{$\begin{array}{l}\text { Soil depth } \\
(0-30 \mathrm{~cm})\end{array}$} & \multicolumn{4}{|c|}{ Distance (m) } & \multirow{2}{*}{$\begin{array}{c}\text { Chi- } \\
\text { square } \\
\left(\chi^{2}\right)\end{array}$} & \multirow[b]{2}{*}{ Remark } \\
\hline & & 30 & 60 & 90 & 125 & & \\
\hline \multirow[t]{4}{*}{$\mathrm{Co}$} & Mean & 0.42 & 0.79 & 0.74 & 0.40 & & \\
\hline & $\mathrm{SD}$ & 0.59 & 0.12 & 0.09 & 0.57 & & \\
\hline & $\mathrm{CV} \%$ & 141 & 15.3 & 12.5 & 141 & 0.218 & NS \\
\hline & Range value & 0.00 to 0.83 & 0.70 to 0.87 & 0.67 to 0.80 & 0.00 to 0.80 & & \\
\hline \multirow[t]{4}{*}{$\mathrm{Zn}$} & Mean & 0.31 & 0.43 & 0.03 & 0.08 & & \\
\hline & $\mathrm{SD}$ & 0.01 & 0.54 & 0.04 & 0.08 & & \\
\hline & $\mathrm{CV} \%$ & 4.56 & 125 & 141 & 106 & 0.507 & NS \\
\hline & Range value & 0.30 to 0.32 & -0.81 to 0.05 & 0.00 to 0.05 & 0.02 to 0.14 & & \\
\hline \multirow[t]{4}{*}{$\mathrm{Ni}$} & Mean & 0.76 & 0.22 & 0.42 & 0.91 & & \\
\hline & SD & 0.31 & 0.19 & 0.47 & 1.00 & & \\
\hline & $\mathrm{CV} \%$ & 40.9 & 88.8 & 111 & 112 & 0.513 & NS \\
\hline & Range value & 0.54 to 0.98 & -0.08 to 0.35 & -0.75 to 0.09 & -1.62 to 0.19 & & \\
\hline \multirow[t]{4}{*}{$\mathrm{Pb}$} & Mean & 0.36 & 0.57 & 0.53 & 0.56 & & \\
\hline & SD & 0.04 & 0.01 & 0.21 & 0.19 & & \\
\hline & $\mathrm{CV} \%$ & 9.96 & 2.48 & 39.1 & 34.4 & 0.057 & NS \\
\hline & Range value & -0.38 to 0.33 & 0.56 to 0.58 & 0.38 to 0.67 & 0.42 to 0.69 & & \\
\hline \multirow[t]{4}{*}{ As } & Mean & 0.11 & 0.19 & 0.93 & 0.19 & & \\
\hline & SD & 0.04 & 0.09 & 0.00 & 0.07 & & \\
\hline & $\mathrm{CV} \%$ & 38.6 & 49.7 & 0.00 & 37.2 & 1.350 & NS \\
\hline & Range value & -0.08 to -0.14 & -0.25 to -0.12 & -0.93 to 0.93 & -0.14 to 0.15 & & \\
\hline \multirow[t]{4}{*}{$\mathrm{Cd}$} & Mean & 0.47 & 0.33 & 0.30 & 0.50 & & \\
\hline & SD & 0.26 & 0.29 & 0.16 & 0.36 & & \\
\hline & $\mathrm{CV} \%$ & 56.3 & 89.2 & 55.1 & 72.9 & 0.075 & NS \\
\hline & Range value & 0.28 to 0.65 & 0.12 to 0.53 & 0.18 to 0.41 & 0.24 to 0.75 & & \\
\hline \multirow[t]{4}{*}{$\mathrm{Cr}$} & Mean & 0.17 & 0.12 & 0.54 & 1.06 & & \\
\hline & SD & 0.11 & 0.04 & 0.13 & 0.51 & & \\
\hline & $\mathrm{CV} \%$ & 64.3 & 35.4 & 23.8 & 48.0 & 1.200 & NS \\
\hline & Range value & 0.09 to 0.24 & 0.09 to 0.15 & 0.45 to 0.63 & -1.42 to 0.70 & & \\
\hline \multirow[t]{4}{*}{$\mathrm{Cu}$} & Mean & 1.78 & 1.28 & 0.68 & 1.78 & & \\
\hline & $\mathrm{SD}$ & 1.38 & 0.74 & 0.11 & 1.38 & & \\
\hline & $\mathrm{CV} \%$ & 77.7 & 58.2 & 15.7 & 77.7 & 0.205 & NS \\
\hline & Range value & -2.75 to -0.80 & -1.80 to -0.75 & -0.60 to 0.75 & -2.75 to -0.80 & & \\
\hline
\end{tabular}

NS $=$ Not significantly different at $\alpha=0.05$ (critical value $=7.82$ ) Note: Degree of freedom, $\mathrm{df}=\mathrm{k}-1=4-1=3$

Ado-Ekiti, Nigeria. Laterally, the relative pollution potentials of the heavy metals were in the order of $125 \mathrm{~m}>$ $60 \mathrm{~m}>30 \mathrm{~m}>90 \mathrm{~m}$.

\section{Conclusion}

Results obtained from this study revealed that the heavy metal pollution level as indicated by the geoaccumulation index $\left(\mathrm{I}_{g e o}\right)$ and the relative pollution potential of the surface and subsurface soils from the Sawmill were classified as unpolluted to moderately polluted soils with the studied heavy metals. The subsurface pollution indices values were higher than that of the surface depths. Although the findings indicated less polluted soils in the Sawmill but it should be noted that over a period, sawmill wastes contributes significantly to the relative heavy metals concentration in soils. Hence, there should be development of pollution prevention and reduction strategies to reduce the potential heavy metal pollution for areas undergoing spontaneous industrialization and urbanization. 


\section{References}

Achadu OI, Ocholi IO, Ahmadu AO and Njoku UP (2016), Assessment of heavy metals levels and leaching potentials in dumpsites soils in Wukari, North-Eastern Nigeria, Int. J. Mod. Anal. Separat. Sci. 5(1): 20-31.

Adaikpoh EO (2013), Distribution and enrichment of heavy metals in soils from waste dump sites within Imoru and environs, Southwest, Nigeria, J. Environ. Earth Sci. 3: 45-54.

Adriano DC, Bolan NS, Bon-Jun K, Naidu R, Lelie D, Vangrousveld J and Wenzel WW (2002), Natural remediation processes: Bioavailability interactions in contaminated soils, Symposium No. $42,17^{\text {th }}$ WCSS, Thailand, 501.

Aweto AO (1982), Variability of upper slope soils development under sandstones in south-western Nigeria. Geograph. J. 25: 1-5.

Ayodele OJ and Shittu OS (2016), Heavy metal contents of soils and plants as influenced by leached ash refuse from black soap-making at Ikere-Ekiti, Nigeria, $J$. Environ. Sci., Toxic. and Food Tech. 10: 35-40.

Chakra-borty R, Zaman S, Mukhopadhyay N, Banerjee K and Mitra A (2009), Seasonal variation of $\mathrm{Zn}, \mathrm{Cu}$ and $\mathrm{Pb}$ in the estuarine stretch of west Bengal, Indian J. Marine Sci. 38(1): 104-109.

Egharevba F and Odjada V (2002), The pollution potential and chemical interaction parameter of some agro and industrial wastes on soil, Nig. J. Basic Appl.Sci. 11: $177-188$.

Inengite AK, Abasi CY and Walter C (2015), Application of pollution indices for the assessment of heavy metal pollution in flood impacted soil, Int. Res. J. Pur. Appl. Chem. 8(3): 175-189.

Karbassi AR, Monavari SM, NabiBidhendi GR, Nouri J and Nematpour K (2008), Metal pollution assessment of sediment and water in the Shur River, Environ. Monitor. Assess. 147(1-3): 107-116.

Kargar M, Khorasani NA, Karami M, Rafiee GH and Naseh $\mathrm{R}$ (2012), An investigation on $\mathrm{As}, \mathrm{Cd}$, Mo and $\mathrm{Cu}$ contents of soils surrounding the Meyduk tailing dam, Int. J Environ. Res. 6(1): 173-184.
Loska K, Cebula J, Pelezar J, Wiechula D and Kwapulinski J (1997), Use of enrichment and contamination factors together with geoaccumulation indexes to evaluate the content of $\mathrm{Cd}, \mathrm{Cu}$, and $\mathrm{Ni}$ in the Rybnik Water Reservoir in Poland, Wat. Air and Soil Pollut. 93: 347-365.

Muller G (1969), Index of geoaccumulation in the sediments of the Rhine River, Geojournal 2: 108-118.

Muller G (1981), Die Schwermetallbelstung der sediment des Neckars und seiner Nebenflusse: EineBestandsaufnahme. Chemiker Zeitung 105: 156-164.

Okonkwo CI, Arinzechukwu P and Njoku C (2013), Changes in physical and chemical properties of soil in timber sawmill dumpsite in Abakaliki, Abakaliki Southeastern, Nigeria, Brit. J. Environ. Clim. Change 3(2): 215-228.

Ololade IA (2014), An assessment of heavy metal contamination in soils within auto mechanic workshops using enrichment and contamination factors with geoaccumulation indexes, J. Environ. Prot. 5: 970-982.

Osakwe AS (2013), Assessment of the effects of wood processing industries in selected parts of Delta State, Nigeria, on the soils and vegetation in their vicinities, J.Appl. Chem. 3(3): 22-30.

Osakwe SA (2014), Heavy metal contamination and physicochemical characteristics of soils from automobile workshops in Abraka, Delta State, Nigeria. Int. J. Nat. Sci. Res. 2(4): 48-58.

Panshin AJ, Harrar ES, Baker WJ and Proctor PB (1950), Forest products, their sources, production and utilization, McGraw-Hill Book Company, Inc., New York, p 527.

Wang J, Liu W, Yang R, Zhang L and Ma J (2013), Assessment of the potential ecological risk of heavy metals in reclaimed soils at an opencast coal mine, Disaster Advances 6(S3): 366-377. 